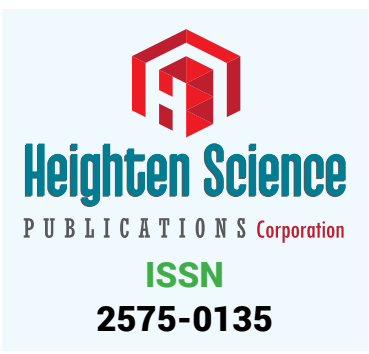

*Address for Correspondence: Dr. Mohsin Tariq, Government College University Faisalabad, Pakistan, Tel: 0092-333-6601612; Email: mohsintariq@gcuf.edu.pk; mruaf@hotmail.com

Submitted: 17 May 2017

Approved: 31 May 2017

Published: 02 June 2017

Copyright: @ 2017 Tariq M, et al. This is an open access article distributed under the Creative Commons Attribution License, which permits unrestricted use, distribution, and reproduction in any medium, provided the original work is properly cited.

Keywords: PGPR; Antagonism; Siderophores; Antibiotics; Bacteriocins; Lytic enzymes
Mini Review

\section{Antagonistic features displayed by Plant Growth Promoting Rhizobacteria (PGPR): A Review}

\author{
Mohsin Tariq ${ }^{1 *}$, Muhammad Noman', Temoor Ahmed ${ }^{1}$, Amir \\ Hameed ${ }^{1}$, Natasha Manzoor ${ }^{2}$ and Marriam Zafar ${ }^{2}$ \\ 'Government College University Faisalabad, Pakistan \\ ${ }^{2}$ University of Agriculture Faisalabad, Pakistan
}

\section{ABSTRACT}

Soil dwelling bacteria able to colonize plant roots and closely associated soil are referred to as rhizobacteria. A wide range of rhizobacteria has the ability to promote plant growth directly by producing phytohormone and nutrients; and indirectly by controlling plant pathogen. These beneficial bacteria are known as plant growth promoting rhizobacteria (PGPR). PGPR control phytopathogens by producing chemicals that could damage pathogen cells, removing pathogen specific nutrients from the environment, or inducing resistance against pathogen in plant body. Antagonistic bacteria specifically damage pathogens by producing lytic enzymes, antibiotics and bacteriocins; and excluding pathogen from plant environment by siderophores oriented iron chelation. This review highlights the antagonistic feature of PGPR. Application of antagonistic bacteria as biopesticides is an attractive alternate of chemical pesticides. Chemical pesticides are non-targeted and cause pollution during its synthesis as well as at the site of application. Antagonistic bacteria could be used as biopesticides and biofertilizers for better plant health and growth improvement.

\section{PLANT GROWTH PROMOTING RHIZOBACTERIA}

Rhizosphere is a narrow zone of soil directly influenced by the secretions of root system [1]. This is a nutrient rich zone as compared to the bulk soil due to the accumulation of root exudates carrying a large amount of carbohydrates and amino acids, serve as a rich source of energy and nutrients for soil associated microbes. Rhizosphere is enriched with a variety of microorganisms and the bacteria residing in this region are called rhizobacteria [2]. Bacteria associated with plants are classified into different group's i.e. beneficial, deleterious and neutral groups according to their effects on plants [3]. Beneficial bacteria living in the rhizosphere are known as plant growth promoting rhizobacteria (PGPR) [4]. PGPR are agriculturally important bacteria having specific symbiotic relationships with plants. The PGPR enhance plant growth and health by suppressing plant pathogens and making different nutrients available to plants [5,6]. Kloepper introduced the term PGPR in late 1970s and described PGPR as "Soil living bacteria that colonize or incorporate plants roots and improves the growth of plant" [4,7]. PGPR can also be termed as plant health promoting rhizobacteria (PHPR) or nodule promoting rhizobacteria (NPR) and are attached with the rhizosphere that is an important ecological environment of soil for plant-microbe interactions [8].

Plant growth and health improvement by PGPR are regulated by various direct and indirect mechanisms. Direct plant growth promotion by PGPR involves either providing plants with microbe-oriented compounds or helping in the absorption of several nutrients from the environment that are essential for plant growth. However, rhizobacteria also have the ability to indirectly benefit plant by excluding and reducing 
the rhizosphere dwelling plant pathogens $[9,10]$. Application of PGPR for the purpose of controlling or lessening the harmful effects of phytopathogens is known as biological control. PGPRs control the detrimental effects of pathogenic agents on plants by producing growth inhibitors i.e. antibiotics, bacteriocins, siderophores and lytic enzymes or by increasing natural resistance of host plant. Antagonistic activity of PGPR is regulated by several mechanisms including competition, parasitism, and siderophores or antibiotics production [11,12]. Various species of rhizobacteria belonging to the genera Alcaligenes, Arthrobacter, Azospirillum, Azotobacter, Bacillus, Bradyrhizobium, Burkholderia, Enterobacter, Flavobacterium, Klebsiella, Mesorhizobium, Pseudomonas, Rhodococcus, Streptomyces, Serratia etc. have been reported to promote plant growth and antagonize plant pathogens [13-15].

Nutrient uptake, yield and growth is influenced by plant growth-promoting bacteria (PGPB) through various mechanisms. Plant physiology is directly regulated by few bacterial strains through the synthesis of phyto-hormones, whereas others enhance the plant growth by increasing the availability of mineral and nitrogen in the soil. The genera such as Azospirillum, Azotobacter, Acetobacter diazotrophicus, Azoarcus include bacterial species that have the ability to fix nitrogen biologically. Besides biological nitrogen fixation, phosphate solubilization is also an important phenomenon in the rhizosphere that enhance the nutrient availability to the host plant [16]. For instance, Cattelan et al. [17] discovered that only two isolates from rhizosphere out of five are positive for P solubilization and soybean seedling growth is positively affected by these strains [18]. This review mainly focuses antagonistic features of PGPR and its beneficial effects on the agricultural system.

\section{ANTAGONISTIC BACTERIA}

Chemical pesticides have been practiced since many decades in agriculture to successfully control the pest and thus increasing the crop production [19]. The one of the major disadvantage of chemical pesticides is that many of them are not able to breakdown into simple and safer constituents and remained intact over a long time period polluting soil environmental [20]. Synthetic pesticides are also non-targeted in nature as they affect the broad spectrum of microbe including plant beneficial microbe. Biopesticide is an appealing alternative to chemical pesticide. Biopesticides have various advantages over conventional pesticides. Biopesticides are safe to use as compared to synthetic pesticides and have targeted activity against specific pathogens. It can also be easily decomposed than conventional pesticides [21]. Some of the biopesticides e.g. Bacillus thuringiensis have a long history of safe and effective use as bio-insecticide. $B$. thuringiensis has been the most widely studied and utilized insecticidal bacterium; registered in United States (US) for commercial use since 1961 [22]. Antagonistic potential of PGPR can be exploited as biopesticides on commercial scale for sustainable agriculture system [2].

Rhizobacteria can inhibit the growth of several phytopathogens in different ways; competing for space and nutrients, producing bacteriocins, lytic enzymes, antibiotics and siderophores [23]. These antagonistic bacteria specifically disintegrate the cells of pathogens by producing lytic enzymes, antibiotics and bacteriocins. Similarly, antagonistic bacteria deprive the pathogen from iron by producing siderophores to chelate it, ultimately exclude the pathogen from niche [2]. Eubacterial genera including Bacillus, Burkholderia, Enterobacter, Herbaspirillum, Ochrobactrum, Pseudomonas, Serratia, Staphylococcus and Stenotrophomonas are well known antagonistic bacteria. These bacteria have been broadly described for a wide range of antagonistic activities to combat phytopathogens [24-26]. Production of siderophores, antibiotics, bacteriocins and lytic enzymes is extensively studied amongst antagonistic bacteria.

\section{Siderophores}

Siderophores are the low molecular weight substances that chelate iron. Microorganisms encounter the nutritional requirements for iron using siderophores. 
In surrounding environment, the iron is solubilized when siderophores are released and a ferric-siderophore complex is formed and this substance move through diffusion process and reached to cell surface surface [27]. Membrane receptors of gram-positive and gram-negative bacteria recognize ferric-siderophore complex and start the active transport [28]. Siderophores have great affinity to form complex with ferric ion, improve its solubilization and enabling its removal from natural complexes or from minerals [29]. Low ferric ions availability in the environment results in the reduced growth of pathogens, which ultimately exclude pathogen from niche (Hibbing et al. 2010).

Siderophores are peptide molecules that include the functional groups along with side chains that enhance the regulation of ferric ions by forming high affinity set of ligands [30]. Bacterial siderophores are classified into four major classes based on the types of ligand and basic features of functional groups that form coordinate with iron. Main classes include phenol catecholates, carboxylate, pyoverdines and hydroxamates [31]. Production of siderophores plays important role to reduce phytopathogens proliferation by iron chelation and enhance plant development by increased uptake of iron [32-34]. Ferric-siderophore complex has significant influence on uptake of iron by plants when other metals like cadmium and nickel are present [2]. Iron plays a vital role in cellular growth and metabolism, such that Fe acquisition through siderophore production is an important factor in deciding the competitive fitness of bacteria to grow in the plant roots vicinity and to compete with other microbes for iron in the rhizosphere [35]. Siderophores produced by Pseudomonas recognized for their high affinity with ferric ion. Pyoverdines are effective siderophore that can suppress the growth rate of fungi and bacteria that are not effective in iron depletion in-vitro conditions. P. putida produce the pseudofactin siderophore that have ability to abolish the Fusarium oxysporum and Rhizoctonia solani from rhizosphere by lowering iron availability in soil [2].

\section{Antibiotics}

The production of antibiotics is assumed as most effective treatment and have antagonistic activity to suppress the phytopathogens. Antibiotics are organic compounds of low molecular weight that are involved in the inhibition of growth and metabolic activities of various microbes. The production of antibiotics is the most effective antagonistic activity to suppress the growth of phytopathogens $[35,36]$. Thus, antibiotics play an important role in disease management i.e. can be used as biocontrol agents [37]. Antibiotics produced by PGPR include kanosamine, 2, 4-diacetylphloroglucinol (2, 4-DAPG), Martínez-Viveros oligomycin A, butyrolactones, xanthobaccin phenazine-1-carboxylic acid, pyrrolnitrin, zwittermycin $A$, viscosinamide [38]. The bacterial strain of $P$. fluorescens BL915 involve in the production of antibiotic known as pyrrolnitrin have ability to inhibit deterioration of Rhizoctonia solani. 2, 4-DAPG is an extensively studied antibiotic involved in the membrane destruction of Pythium spp. [39]. Pseudomonas spp. also synthesizes phenazine that contains the antagonistic activity against Fusarium oxysporum [2]. Many Bacillus ssp. produced antibiotics like circulin, polymyxin and colistin that are actively involved in the growth inhibition of pathogenic fungi as well as Gram-negative and Gram-positive bacteria. Bacillus subtilis produce antibiotics such as fengycin and iturins and inhibit the growth of a fungus named Podosphaera fusca $[40,41]$. Antibiotics play an important role in disease management, used as biocontrol agent and faced challenge due to limitations because antibiotics are prepared under natural circumstances. Ecological and other components that effect the antimicrobial action of antibiotics were examined to utilize the potential of antibiotics that are produced by PGPR in crop protection [37].

\section{Bacteriocins}

Bacteriocins are proteinaceous toxins that are secreted by bacteria that lives in competitive microbial environment. They destroy the neighboring bacterial species by damaging the bacterio-cinogenic cells [42]. Bacteriocins are very effective in reducing 
or inhibiting the growth of phytopathogens [2]. Bacteriocins have narrow killing spectrum as compared to conventional antibiotics and these have damaging effect on the bacteria that are closely relative of bacteriocin producing bacteria [42]. Colicins are most prominent bacteriocins synthesized by Escherichia coli. Similarly, megacins is produced by B. megaterium; marcescins from Serratia marcescens; cloacins from Enterobacter cloacae; and pyocins comes from P. pyogenes [43]. Bacteriocins that are produced by Bacillus spp. remarkably gain importance due broad range of inhibition of fungal, yeast, gram positive and gram negative species that may have some pathogenic effect on animals and human beings [44].

\section{Lytic enzymes}

Many polymeric compounds like cellulose, hemicellulose, chitin and protein can be hydrolyzed by the lytic enzymes produced by various microorganisms. Microbes can directly suppress the growth and activities of pathogens by the secreting lytic enzymes. Hydrolytic enzymes including glucanases, proteases, chitinases, lipases etc, are involved the lysis of fungal cell wall [45]. These enzymes either digest the enzymes or deform components of cell wall of fungal pathogens. It is one of the important mechanisms for environment friendly control of soil-borne pathogen [46]. These enzymes also decompose nonliving organic matter and plant residues to obtain carbon nutrition. Lytic enzymes produced by Myxobacteria are effective in the suppression of fungal plant pathogens [47,48]. Antagonistic bacteria Serratia marcescens reduce mycelial network of Sclerotium rolfsii by expressing chitinase [49]. Lysobacter is capable of producing glucanase that is involved in the control of diseases caused by Bipolaris and Pythium sp. [50]. Hydrolytic enzymes directly contribute in the parasitization of phytopathogens and rescue plant from biotic stresses [51].

\section{CONCLUSION}

Chemical pesticides suppress phytopathogens for improved plant growth and health; nevertheless damage non-targeted beneficial microorganisms of soil and pollute soil environment. Biopesticides are environment friendly and target only phytopathogens. Biopesticides consisting of antagonistic bacteria has been explored since long and registered for commercial use since 1960s, but this strategy has yet not been fully searched and adopted. One of the reasons for restricted research on antagonistic bacteria is that mostly their antagonist potential is tested against pathogens at a higher biosafety level laboratory. So, this research work needs separate laboratory facility and also sometime tricky for lab personnel. Secondly, this area demands huge investment and keen interest of the environmental authorities to run sustainable agriculture system based biopesticides, biofertilizer and environment friendly solution. Adoption of PGPR based biopesticides to combat phytopathogens and promote plant growth may substantially contribute to sustainable agriculture and safe environment.

\section{REFERENCES}

1. Walker TS, Bais HP, Grotewold E, Vivanco JM. Root exudation and rhizosphere biology. Plant Physiol. 2003; 132 44-51. Ref.: https://goo.gl/B7urwj

2. Beneduzi A, Ambrosini A, Passaglia LM. Plant growth-promoting rhizobacteria (PGPR): their potential as antagonists and biocontrol agents. Genet Mol Biol. 2012; 35: 1044-1051. Ref.: https://goo.gl/YgOLNL

3. Dobbelaere S, Vanderleyden J, Okon Y. Plant growth-promoting effects of diazotrophs in the rhizosphere. Crit Rev in Plant Sci. 2003; 22: 107-149. Ref.: https://goo.gl/SqyHVQ

4. Kloepper JW, Lifshitz R, Zablotowicz RM. Free-living bacterial inocula for enhancing crop productivity. Trends Biotechnol. 1989; 7: 39-44. Ref.: https://goo.gl/3RwbZu

5. Tariq M, Hameed S, Khan HU, Munir MI, Nushin F, et al. Role of microsymbionts in plant microbe symbiosis. J Appl Microbiol Biochem. 1989; 2: 1.

6. Babalola 00. Beneficial bacteria of agricultural importance. Biotechnol Lett. 2010; 32: 1559-1570. Ref.: https://goo.gl/3lkL9V 
7. Gray E, Smith D. Intracellular and extracellular PGPR: commonalities and distinctions in the plant-bacterium signaling processes. Soil Biol Biochem. 2005; 37: 395-412. Ref.: https://goo.gl/MZTy6q

8. Hayat R, Ali S, Amara U, Khalid R, Ahmed I. Soil beneficial bacteria and their role in plant growth promotion: a review. Ann of Microbiol. 2010; 60: 579-598. Ref.: https://goo.gl/OrOKqH

9. Singh SR, Joshi D, Singh P, Srivastava TK, Tripathi N. Plant growth-promoting bacteria: an emerging tool for sustainable crop production under salt stress, in bioremediation of salt affected soils. An Indian Perspective. 2017; 101-131. Ref.: https://goo.gl/v79LxJ

10. Ahemad M, Kibret M. Mechanisms and applications of plant growth promoting rhizobacteria: current perspective J King Saud Univ Sci. 2014; 26: 1-20. Ref.: https://goo.gl/4xLO6A

11. Anith KN, Momol MT, Kloepper JW, Marois JJ, Olson SM, et al. Efficacy of plant growth-promoting rhizobacteria, acibenzolar-S-methyl, and soil amendment for integrated management of bacterial wilt on tomato. Plant Dis. 2004; 88: 669-673. Ref.: https://goo.gl/2CD2WT

12. Paul D, Kumar A, Anandaraj M, Sarma YR. Studies on the suppressive action of fluorescent Pseudomonas on Phytophthora capsici, the foot rot pathogen of black pepper. Indian Phytopathol. 2001; 54: 515.

13. Tariq M, Hameed S, Yasmeen T, Zahid M, Zafar M. Molecular characterization and identification of plant growth promoting endophytic bacteria isolated from the root nodules of pea (Pisum sativum L.). World J Microbiol Biotechnol. 2014; 30: 719-725. Ref.: https://goo.gl/j9VV7V

14. Gupta A, Gupta R, Singh RL. Microbes and environment, in principles and applications of environmental biotechnology for a sustainable future. 2016; 43-84. Ref.: https://goo.gl/93bv1t

15. Ahmad F, Ahmad I, Khan M. Screening of free-living rhizospheric bacteria for their multiple plant growth promoting activities. Microbiol Res. 2008; 163: 173-181. Ref.: https://goo.gl/5ZclSI

16. Saharan B, Nehra V. Plant growth promoting rhizobacteria: a critical review. Life Sci Med Res. 2011; 21: 30. Ref.: https://goo.gl/xRS2E0

17. Cattelan AJ, Hartel PG, Fuhrmann JJ. Screening for plant growth-promoting rhizobacteria to promote early soybean growth. Soil Sci Socie Amer J. 1999; 63: 1670-1680. Ref.: https://goo.gl/sxEkV5

18. Kevin Vessey J. Plant growth promoting rhizobacteria as biofertilizers. Plant and soil. 2003; 255: 571-586. Ref.: https://goo.gl/vcpFdj

19. Paoletti MG, Pimentel D. Environmental risks of pesticides versus genetic engineering for agricultural pest Control. J Agric Environ Ethics. 2000; 12: 279-303. Ref.: https://goo.gl/vtBij1

20. Gilden RC, Huffling K, Sattler B. Pesticides and Health Risks. J Obstet Gynecol Neonatal Nurs. 2010; 39: 103-110. Ref.: https://goo.gl/gxvUAl

21. Thakore Y. The biopesticide market for global agricultural use. Ind Biotechnol. 2006; 2: 194-208. Ref.: https://goo.gl/o40S7x

22. Sudakin DL. Biopesticides. Toxicol Rev. 2003; 22: 83-90. Ref.: https://goo.gl/yuWolE

23. Jing YD, He ZL, Yang XE. Role of soil rhizobacteria in phytoremediation of heavy metal contaminated soils. J Zhejiang Univ Sci B. 2007; 8: 192-207. Ref.: https://goo.gl/H91eSp

24. Tariq M, Yasmin S, Hafeez FY. Biological Control of Potato Black Scurf by Rhizosphere Associated Bacteria. Braz J Microbiol. 2010; 41: 439-451. Ref.: https://goo.gl/t7hSpg

25. Berg G. Plant-microbe interactions promoting plant growth and health: perspectives for controlled use of microorganisms in agriculture. Appl microbiol biotechnol. 2009; 84: 11-18. Ref.: https://goo.gl/cCbjJ1

26. Soylu S, Soylu EM, Kurt S, Ekici OK. Antagonistic potentials of rhizosphere-associated bacterial isolates against soil-borne diseases of tomato and pepper caused by Sclerotinia sclerotiorum and Rhizoctonia solani. Pak J Biol Sci. $2005 ; 8$ : 43-48.

27. Andrews SC, Robinson AK, Quiñones FR. Bacterial iron homeostasis. FEMS Microbiol Rev. 2003; 27: 21 5-237. Ref.: https://goo.gl/iBFgPM

28. Boukhalfa H, Crumbliss AL. Chemical aspects of siderophore mediated iron transport. Biometals. 2002; 15: 325339. Ref.: https://goo.gl/GnlFoz

29. Zhou D, Huang XF, Chaparro JM, Badri DV, Manter DK, et al. Root and bacterial secretions regulate the interaction between plants and PGPR leading to distinct plant growth promotion effects. Plant Soil. 2016; 401: 259-272. Ref.: https://goo.gl/mDrVtr

30. Crosa $\mathrm{JH}$, Walsh CT. Genetics and assembly line enzymology of siderophore biosynthesis in bacteria. Microbio Mol Biol Rev. 2002; 66: 223-249. Ref.: https://goo.gl/km7s8x 
31. Crowley DE. Microbial siderophores in the plant rhizosphere. In Iron nutrition in plants and rhizospheric microorganisms. 2006; 169-198. Ref.: https://goo.gl/JEEcHy

32. Hibbing ME, Fuqua C, Parsek MR, Peterson SB. Bacterial competition: surviving and thriving in the microbial jungle Nature Rev Microbiol. 2010; 8: 15-25. Ref.: https://goo.gl/eJACWD

33. Masalha $\mathrm{J}$, Kosegarten $\mathrm{H}$, Elmaci $\mathrm{O}$, Mengel $\mathrm{K}$. The central role of microbial activity for iron acquisition in maize and sunflower. Biol Fertil Soils. 2000; 30: 433-439. Ref.: https://goo.gl/9qzc20

34. Katiyar V, Goel R. Siderophore mediated plant growth promotion at low temperature by mutant of fluorescent pseudomonad. Plant Growth Regul. 2004; 42: 239-244. Ref.: https://goo.gl/pck86D

35. Haas D, Défago G. Biological control of soil-borne pathogens by fluorescent pseudomonads. Nature Rev Microbiol. 2005; 3: 307-319. Ref.: https://goo.gl/v7AgPZ

36. Bharti P, Tewari R. Purification and structural characterization of a phthalate antibiotic from Burkholderia gladioli OR1 effective against multi-drug resistant Staphylococcus aureus. The J Microb Biotech Food Sci. 2015; 5: 207. Ref.: https://goo.gl/nM6fIU

37. Fernando WD, Nakkeeran S, Zhang Y. Biosynthesis of antibiotics by PGPR and its relation in biocontrol of plant diseases, in PGPR: biocontrol and biofertilization. 2005; 67-109. Ref.: https://goo.gl/Be6Esz

38. Viveros OM, Jorquera MA, Crowley DE, Gajardo G, Mora ML. Mechanisms and practical considerations involved in plant growth promotion by rhizobacteria. J Soil Sci Plant Nutr. 2010; 10: 293-319. Ref.: https://goo.gl/0lur11

39. de Souza JT, Arnould C, Deulvot C, Lemanceau P, Gianinazzi-Pearson V, et al. Effect of 2, 4-diacetylphloroglucinol on Pythium: cellular responses and variation in sensitivity among propagules and species. Phytopathology. 2003; 93: 966-975. Ref.: https://goo.gl/W82qUA

40. Maksimov I, Abizgil Dina R, Pusenkova L. Plant growth promoting rhizobacteria as alternative to chemical crop protectors from pathogens (review). Appl Biochem Microbiol. 2011; 47: 333-345. Ref.: https://goo.gl/whQnu3

41. Romero D, de Vicente A, Rakotoaly RH, Dufour SE, Veening JW, et al. The iturin and fengycin families of lipopeptides are key factors in antagonism of Bacillus subtilis toward Podosphaera fusca. Mol Plant-Microbe Interact. 2007; 20, 430-440. Ref.: https://goo.gl/eKBD0G

42. Riley MA, Wertz JE. Bacteriocins: evolution, ecology, and application. Annu Rev Microbiol. 2002; 56: 117-137. Ref.: https://goo.gl/Jlxy1C

43. Cascales E, Buchanan SK, Duche D, Kleanthous C, Lloubes R, et al. Colicin biology. Microbiol Mol Biol. 2007; 71: 158-229. Ref.: https://goo.gl/scomLV

44. Abriouel H, Franz CM, Omar NB, Galvez A. Diversity and applications of Bacillus bacteriocins. FEMS Microbiol Rev 2011; 35: 201-232. Ref.: https://goo.gl/3i7QnL

45. Neeraja C, Anil K, Purushotham P, Suma K, Sarma $P$, et al. Biotechnological approaches to develop bacterial chitinases as a bioshield against fungal diseases. Crit Rev Biotechnol. 2010; 30: 231-241. Ref.: https://goo.gl/g4BLjp

46. Aeron A, Pandey P, Kumar S, Maheshwari DK. Emerging role of plant growth promoting rhizobacteria. D.K. Maheshwari (Ed.). Bacteria in agrobiology: crop ecosystem. 2001; 1-26. Ref.: https://goo.gl/YM5gKU

47. Kobayashi D, El-Barrad NH. Selection of bacterial antagonists using enrichment cultures for the control of summer patch disease in kentucky bluegrass. Curr Microbiol. 1996; 32: 106-110. Ref.: https://goo.gl/OLnl6K

48. Bull CT, Shetty KG, Subbarao KV. Interactions between Myxobacteria, plant pathogenic fungi, and biocontrol agents. Plant Dis. 2002; 86: 889-896. Ref.: https://goo.gl/Jrgfxw

49. Ordentlich A, Elad $\mathrm{Y}$, Chet I. The role of chitinase of Serratia marcescens in biocontrol of Sclerotium rolfsii Phytopathology. 1988; 78: 84-88. Ref.: https://goo.gl/16Jfk1

50. Palumbo JD, Yuen GY, Jochum CC, Tatum K, Kobayashi DY. Mutagenesis of Beta-1,3-Glucanase Genes in Lysobacter Enzymogenes Strain C3 Results in Reduced Biological Control Activity Toward Bipolaris Leaf Spot of Tall Fescue and Pythium Damping-Off of Sugar Beet. Phytopathol. 2005; 95: 701-707. Ref.: https://goo.gl/lpRnHe

51. Haran S, Schickler H, Chet I. Molecular mechanisms of lytic enzymes involved in the biocontrol activity of Trichoderma harzianum. Microbiol. 1996; 142: 2321-2331. Ref.: https://goo.gl/QX3ZUz 